\title{
EARLY OCCURRENCE OF A PENNSYLVANIAN-AGE MEDULLOSALEAN FROND SIMILAR TO ALETHOPTERIS PSEUDOGRANDINIOIDES IN THE INTRA-MONTANE BASIN OF BOHEMIA
}

\author{
ZBYNĚK ŠIMŮNEK' CHRISTOPHER J. CLEAL2,** \\ ${ }^{1}$ Czech Geological Survey, Klárov 131/3, 11821 Praha 1, the Czech Republic; e-mail: zbynek.simunek@geology.cz. \\ 2 Department of Biodiversity and Systematic Biology, National Museum Wales, Cathays Park, Cardiff CF10 3NP, United Kingdom; e-mail: \\ chris.cleal@museumwales.ac.uk. \\ * corresponding author
}

Šimůnek, Z., Cleal, C. J. (2018): Early occurrence of a Pennsylvanian-age medullosalean frond similar to Alethopteris pseudograndinioides in the intra-montane basin of Bohemia. - Fossil Imprint, 74(1-2): 37-44, Praha. ISSN 2533-4050 (print), ISSN 2533-4069 (on-line).

\begin{abstract}
A single frond fragment found in the lower Bolsovian Substage of Central and Western Bohemia (the Czech Republic) closely resembles Alethopteris pseudograndinioides ZoDROw et CLEAL, a species not normally seen until rather younger, late Asturian floras. This discovery provides further evidence that some of the species that suddenly proliferated in mid-Asturian times in response to climate and/or landscape changes, originated in the upland vegetation of the Variscan Mountains.
\end{abstract}

Key words: Palaeobotany, Medullosales, Westphalian, Alethopteris

Received: October 11, 2017 | Accepted: January 8, 2018 | Issued: August 31, 2018

\section{Introduction}

The vegetation of the Pennsylvanian-age (late Carboniferous) tropical wetlands of Euramerica underwent a major change in late Westphalian times, most notably with the replacement of lycopsids by marattialean ferns as the dominant trees of the peat-substrate habitats. This is clearly reflected in the palaeontological record of the coals (palynology and coal balls, e.g. Phillips et al. 1985), and has been variously interpreted as a response to climate change (Phillips and Peppers 1984, Phillips and Cecil 1985, DiMichele et al. 1985, DiMichele and Phillips 1996, Gastaldo et al. 1996), landscape change (Cleal and Thomas 1999, 2005), or a combination of the two (Cleal et al. 2010, 2011). However, there were also notable changes in the vegetation of the clastic substrate habitats, especially among the seed-bearing plants ("pteridosperms") whose remains tend to dominate the adpression floras found between the coal seams, with the appearance of callistophytes (Dicksoniites foliage) and an increase in diversity of the larger-leaved medullosaleans (especially Alethopteris). In most parts of Variscan Euramerica (i.e. the areas of eastern North America and Europe east of the Acadian Highlands sensu Pfefferkorn and Gillespie 1980) this change in the adpression floras is recognisable in the middle Asturian Substage and is used as an index to the base of the Crenulopteris acadica Zone (formerly Lobatopteris vestita Zone sensu Wagner 1984). However, there is some evidence that the change in adpression floras may occur a little earlier in the intra-montane basins; in the Saar-Lorraine Basin on the Franco-German border, for instance, alethopterids become noticeably more abundant in the middle Westphalian Sulzbach Formation Paripteris linguaefolia Zone).

The present paper reports on a rare occurrence of an alethopterid in the lower Bolsovian Substage of Central and Western Bohemia, which looks somewhat similar to Alethopteris pseudograndinioides Zodrow et ClEAL, a species not normally seen below the middle Asturian Substage. Although it is just a single occurrence, this specimen has yielded cuticles to support our suggested identification.

\section{Material and methods}

The specimen described here is from the upper Radnice Member (lower Kladno Formation) exposed in the Filip II Quarry, Lubná, Kladno-Rakovník Coalfield, the Czech Republic. The specimen is now in the collections of the Czech Geological Survey (inventory number CGS ZŠ 793a, b).

The cuticles were prepared by macerating part of the specimen in $40 \%$ Schulze Solution and then bleaching with 10\% KOH solution (Barthel 1962, Cleal and Zodrow 1989, Kerp 1991). After washing in distilled water, the cuticles 
were either mounted in glycerine jelly for light microscopy, or mounted on a stub and coated with gold for SEM.

In the Systematic palaeobotany section we have used fossil-taxa (sensu Cleal and Thomas 2010) for taxa below the rank of order, rather than trying to place them in taxa of whole living organisms.

For chronostratigraphy we have mainly used the regional Heerlen Scheme (Wagner 1974, Wagner et al. 2002) as this provides a better temporal resolution of the terrestrial sequences in Europe than the IUGS Global Chronostratigraphy. For discussions on the relationship between these two schemes, see Davydov et al. (2010) and Opluštil et al. (2016).

\section{Geological background}

The Kladno-Rakovník Coalfield represents a part of the Central and Western Bohemian Basin (also including, from west to east, the Plzeň, Manětín, Radnice, Žihle, and Mšeno-Roudnice basins - Pešek 2004) that was formed in a basin that has been interperetd as an upland, intra-montane depression with an estimated elevation of ca. 1,000 $\mathrm{m}$ above sea-level (Opluštil 2005).

The Radnice Member is divided into two units (Opluštil and Sýkorová 1999). The lower Radnice Member consists mainly of fine- to medium-grained grey, green or red-brown unbedded sediments with matrix-supported conglomerates, formed in an alluvial fan to alluvial plain environment; this interval includes the Radnice Group of Coals, with upper and lower Radnice coal seams separated by a tuffaceous layer known as the Whetstone Horizon. The upper Radnice Member is separated from the lower unit by a hiatus representing the Duckmantian-Bolsovian boundary (Opluštil et al. 2016), and consists of coarse sandstones together with the Lubná Group of coals. Several tuffite layers occur within the upper Radnice Member. The fossil described here came from a layer of laminated tuffites above the "Z-tuff", associated with the Upper Lubná Coal, and has been dated as $313.22 \pm 0.04 \mathrm{Ma}$ (i.e. early Bolsovian / early Moscovian age - Opluštil et al. 2016). However, other tuffaceous layers in the surrounding of Z-tuff give slightly younger ages of about 312.3 Ma, i.e. middle Bolsovian (S. Opluštil, pers. com.) Also present in this tuffite are small fragments of extra-basinal plants such as Lesleya and Dicranophyllum.

\section{Systematic palaeobotany}

\section{Order Medullosales Consin, 1960 Fossil-family Alethopteridaceae Corsin, 1960}

Fossil-genus Alethopteris STERnBerg, 1825

\section{Alethopteris cf. pseudograndinioides Zodrow et CleAL, 1998}

Pls 1,2

Description. This species is represented here by just a single broken pinnule preserved as part and counterpart (Pl. 1, Figs 1, 2). The specimen is $10 \mathrm{~mm}$ wide and preserved for a length of $18 \mathrm{~mm}$, with a linguaeform to slightly barreled shape, and rounded to slightly obtuse apex; the base of the pinnule is not fully preserved but shows what may be an incipient basiscopic auricle, and the acroscopic side is somewhat constricted. A prominent midvein extends for most of the pinnule length. Fine lateral veins are emitted from the midvein at an acute angle, arch broadly along most of their length, to meet the pinnule margin at about rightangles. The lateral veins fork three or four times at an acute angle, producing a marginal vein density of ca. 40 per $\mathrm{cm}$.

Adaxial epidermis was thinly cutinised, but relatively large fragments could be obtained (Pl. 1, Figs 3-6). The cells of the intercostal field were isodiametric, polygonal, $45-75 \mathrm{~mm}$ in size. The costal field was formed by elongated polygonal to tetragonal cells that were $20-30 \mathrm{~mm}$ wide and 50-100 mm long. No hairs or trichome bases were observed.

Abaxial epidermis was thinly cutinised and there was a distinct differentiation between the cells of the costal and intercostal fields (Pl. 1, Fig. 7, Pl. 2, Fig. 3). The costal field, covering the lateral veins, was formed by elongate tetragonal, trapezoidal or rarely polygonal cells, $40-110 \mathrm{~mm}$ long and 15-30 mm wide. The intercostal fields had more irregularly shaped randomly oriented polygonal cells 30-75 $\mathrm{mm}$ long and 15-30 $\mathrm{mm}$ wide. The anticlinal walls were straight or bent.

Structured holes (Pl. 1, Fig. 8) occur rarely in the costal field of the abaxial epidermis. They are round and around 25 $\mathrm{mm}$ in diameter.

Anomocytic stomata were restricted to the intercostal fields of the abaxial surface and were randomly oriented (Pl. 2, Fig. 3). The guard cells were sunken and surrounded by 5 to 6 adjacent cells (Pl. 2, Figs 2, 4). The guard cells were reniform with projections in the polar areas, $32-38 \mathrm{~mm}$ long and 7-12 mm wide. The exterior (dorsal) walls of the guard cells had strong thickened lamellae and radial striae except in the polar regions (Pl. 2, Fig. 4). Moreover, the guard cells were strongly cutinised around the pores and at the contact areas with adjacent cells. The central part of the dorsal walls bore characteristic radial striae. The stomatal density (SD) varied from 100 (costal field included) to 130 stomata per $\mathrm{mm}^{2}$ and the stomatal index from 15 to 18 .

Co m p a ris o $\mathrm{s}$. Alethopterids are generally rare in the upper Radnice Member (Němejc 1936, Šimůnek 1988, 2007, Šimůnek and Cleal 2002). The only species to be previously reported from the tuffites above the "Z-tuff" are possible fragments Alethopteris lonchitica STERNBERG; it is better documented from the "Z-tuff" itself. However, the latter species tends to have more elongate linguaeform pinnules, and lateral veins that are less curved, rather denser and fork fewer times (usually only once or occasionally twice). The shorter pinnules in $A$. lonchitica can develop somewhat biconvex pinnules, but here the pinnules tend to have a more acute apex, in contrast to the more rounded apex in the presently described specimen. A. lonchitica has much denser stomata $\left(370\right.$ per $\left.\mathrm{mm}^{2}\right)$ on the abaxial surface and are surrounded by a ring of subsidiary cells (Barthel 1962, Šimůnek 1996, 2007).

The only other alethopterid to be recorded from the upper Radnice Member is Alethopteris distantinervosa R.H.WAGNER, emended by Šimůnek and Cleal (2002). The latter has very similar shaped pinnules, but the veins are much less dense (typically 18-27 per $\mathrm{cm}$ on the pinnules margin) and tend to fork at a wider angle. Cuticles of $A$. distantinervosa from the Whetstone Horizon described by 
Šimůnek (1988) are broadly similar to those obtained from the Upper Lubná Coal specimen in the general configuration of the epidermal cells, but differ in having trichomes on the adaxial surface and papillae on the abaxial surface.

The type of Alethopteris nemejcii R.H.WAGNER originated from the lower Radnice Member and has pinnules of similar size and similar vein density, but which are clearly more subtriangular with an acute apex than in the currently described specimen.

Němejc (1936) and Šimůnek (2007) reported Alethopteris serlii (BRONGNIART) GÖPPERT from the lower Radnice Member, although in the lowland paralic basins it does not appear until late Asturian times (Crenulopteris acadica Zone - e.g. Zodrow and Cleal 1998, Cleal et al. 2010). However, A. serlii has generally longer and more slender pinnules, and the lateral veins often tend to be more flexuous (Wagner 1968, Zodrow and Cleal 1998). The stomatal density is similar in both species but in $A$. serlii they are orientated more parallel to the veins (Zodrow and Cleal 1998).

In floras of similar age in the lowland paralic basins of Euramerica, there is some comparison with Alethopteris corsinii BuIsINE. However, the pinnules tend to be rather more slender and lanceolate, and the veins are straighter, less forked and with a lower density (ca. 30 per $\mathrm{cm}$ on the pinnule margin).

Among early Westphalian alethopterids of Euramerica, only three species are notably abundant (Buisine 1961, Šimůnek 1996). Alethopteris decurrens (ARTIS) ZEILLER is clearly quite different having much more slender, often almost needle-like pinnules and widely forked lateral veins. A. decurrens can also be distinguished by having adaxial epidermal cells that are not so markedly differentiated between the costal and intercostal fields and the guard cells of the stomata lack the thickened lamellae and radial striae (Šimůnek 1996). Alethopteris davreuxii (BRONGNIART) ZEILLER has notably more lanceolate pinnules, and veins that are more flexuous, often verging on the pseudo-anastomosed, and somewhat less dense (30-36 per $\mathrm{cm}$ on pinnule margin); A. davreuxii can also be distinguished by having papillate stomata (Šimůnek 1996). Alethopteris urophylla (BRONGNIART) GöPPERT has less barrel-shaped pinnules, the smaller ones tending to an obliquely subtriangular form (Wagner and Álvarez-Vázquez 2008); and the stomata are smaller and oriented parallel to the veins (Šimůnek 1996).

The closest comparison to the currently described specimen is in fact a species normally found in upper Asturian floras (C. acadica Zone) - Alethopteris pseudograndinioides ZODROW et ClEAL. It also has linguaeform to slightly barrelled pinnules, a well-marked midvein, and broadly curved lateral veins that fork two or four times. The most notable difference is the rather higher vein density (in A. pseudograndinioides it is usually 20-34 per $\mathrm{cm}$ - see Zodrow and Cleal 1998). It is possible that this merely represents an extreme end-member of intra-specific variation but, given its very early stratigraphical occurrence (A. pseudograndinioides has not previously been reliably reported from below the Crenulopteris acadica Zone - see Zodrow and Cleal 1998) we think this unlikely. Hence, we have named it Alethopteris cf. pseudograndinioides.

The cuticles of this Czech specimen also resemble the types of Alethopteris pseudograndinioides (from the upper
Asturian Sydney Mines Formation, Cape Breton, Canada) in the shape and the dimensions of the epidermal cells. The stomatal guard cells of the Canadian specimens were a little smaller and narrower than in the described specimen. The Canadian specimens also show evidence of stomata that were more parallel oriented than in the described specimen. The stomatal density is a little higher in the Canadian specimen - 250 stomata per $\mathrm{mm}^{2}$, whereas the studied specimen has only some $100-130$ stomata per $\mathrm{mm}^{2}$.

\section{Discussion}

Although only a single fragment, this late Westphalian specimen is of interest as it appears to be an early but rare representative of the group of alethopterids that in late Moscovian times became major components of the adpression floras, including notably $A$. psueodgrandinioides, Alethopteris grandinii (BRONGNIART) GöPPERT and Alethopteris ambigua LESQUEREUX. A similar situation can be seen in the floras of the Saar-Lorraine coalfield - an intra-montane basin that straddles the Franco-German border. Here, there occur specimens in the lower Bolsovian Sulzbach and Luisenthal formations that strongly resemble A. ambigua, a species that in the paralic basins also does not appear until the base of the $C$. acadica Zone in the middle Asturian Substage. These Saar-Lorraine specimens, described by Bertrand (1932) as Alethopteris friedelii P.BERTRAND, have an indistinguishable pinnule shape to A. ambigua (and unpublished work by the second author suggests that the epidermal structures are also similar) but differ in the veins being more widely forked.

The function of the rare structured holes observed in the abaxial cuticle is at present uncertain. Similar holes have been figured in abaxial cuticles of Alethopteris zeilleri (RAGOT ex W.Remy et al.) R.H.WAGNer by Kerp and Barthel (1993: pl. 3, figs 2-5) and A. pseudograndinioides by Zodrow and Cleal (1998: pl. 7, fig. 5). In both cases these were interpreted as trichome bases although no actual trichomes were observed (these are quite different from the much larger structures on the adaxial cuticle of $A$. zeilleri, which clearly are trichome bases as they have hairs attached - Kerp and Barthel 1993: pl. 2, figs 6-9). In contrast, Shute and Cleal (2002) interpreted similar structured holes in foliar remains of another medullosalean (Laveinopteris) as hydathodes, based on the observation that the collar surrounding the hole appeared to enter the limb of the leaf, rather than extending out of it as would be expected in a trichomes base; again, no actual trichomes were found attached to these holes. However, we have been unable to confirm the orientation of the shallow cutinised collars that appear to surround the structured holes in $A$. cf. pseudograndinioides and so we reserve judgement as to their function.

The guard cells of Alethopteris cf. pseudograndinioides resemble those of Neuropteris cordata BRONGNIART (Krings 2000) and Blanzyopteris praedentata (GoTHAN) M.KRINGS et KERP (Krings and Kerp 1999). All these species have similar dorsal thickened lamellae and radial striae on the guard cells. Of course, there are many morphological features that enable these species to be distinguished, as well as the greater density of trichomes in Neuropteris cordata and Blanzyopteris praedentata. 


\section{Conclusions}

This specimen suggests that the group of alethopterids that suddenly proliferated in late Westphalian (late Moscovian) times in the lowland paralic basins may have been already present in the upland intra-montane basins in early Moscovian times. It has been suggested that the changes in the late Westphalian floras were a result of the development of better drained substrates, and so perhaps such conditions were already present as a subset of the habitats present in the upland basins during mid-Westphalian times. Alternatively, being associated with fragments of extra-basinal plants may indicate that this alethopterid was also from a plant growing outside of wetlands. Either way, it would seem that the sudden appearance of alethopterids in the paralic basins in the middle Asturian Substage, which represent a major biozonal boundary, was a consequence of plant migration rather than a burst of evolutionary change within the lowland wetlands.

\section{Acknowledgements}

The second author (CJC) is grateful to a grant from the European Union Synthesys Programme (CZ-TAF-6452) that supported his visit to Prague as part of this investigation. Z. Šimůnek is grateful to the Internal Project CGS 323100.

\section{References}

Barthel, M. (1962): Epidermisuntersuchungen an einigen inkohlten Pteridospermenblättern des Oberkarbons und Perms. - Geologie, 11: 1-140.

Bertrand, P. (1932): Bassin houiller de la Sarre et de la Lorraine. I. Flore fossile. 2me Fascicule. Aléthoptéridées. In: Études des Gîtes Mineraux de la France. L. Danel, Lille, pp. 59-107.

Buisine, M. (1961): Contribution a l'étude de la flore du terrain houiller. Les Aléthoptéridées du Nord de la France. - Études Géologiques pour l'Atlas Topographie Souterraine, 1(4): 1-317.

Cleal, C. J., Opluštil, S., Thomas, B. A., Tenchov, Y. (2010): Late Moscovian terrestrial biotas and palaeoenvironments of Variscan Euramerica. - Netherlands Journal of Geosciences, 88: 181-278. https://doi.org/10.1017/S0016774600000846

Cleal, C. J., Opluštil, S., Thomas, B. A., Tenchov, Y. (2011): Pennsylvanian vegetation and climate in tropical Variscan Euramerica. - Episodes, 34: 3-12.

Cleal, C. J., Thomas, B. A. (1999): Tectonics, tropical forest destruction and global warming in the Late Palaeozoic. Acta Palaeobotanica, Supplement 2: 17-19.

Cleal, C. J., Thomas, B. A. (2005): Palaeozoic tropical rainforests and their effect on global climates: is the past the key to the present? - Geobiology, 3: 13-31. https://doi.org/10.1111/j.1472-4669.2005.00043.x

Cleal, C. J., Thomas, B. A. (2010): Botanical nomenclature and plant fossils. - Taxon, 59: 261-268.

Cleal, C. J., Zodrow, E. L. (1989): Epidermal structure of some medullosan Neuropteris foliage from the middle and upper Carboniferous of Canada and Germany. - Palaeontology, 32: 837-882.
Corsin, P. (1960): Classification des Ptéridophytes et des Ptéridospermophytes du Carbonifère. - Bulletin de la Société Géologique de France, Série 7, 2: 566-572.

Davydov, V. I., Crowley, J. L., Schmitz, M. D., Poletaev, V. I. (2010): High-precision U-Pb zircon age calibration of the global Carboniferous time scale and Milankovitch band cyclicity in the Donets Basin, eastern Ukraine. Geochemistry, Geophysics, Geosystems, 11(1): 1-22. https://doi.org/10.1029/2009GC002736

DiMichele, W. A., Phillips, T. L. (1996): Climate change, plant extinction and vegetational recovery during Middle-Late Pennsylvanian transition: the case of tropical peat-forming environments in North America. - In: Hart, M. B. (ed.), Biotic recovery from mass extinction events. Geological Society Special Publication, 102: 201-221. https://doi.org/10.1144/GSL.SP.1996.001.01.14

DiMichele, W. A., Phillips, T. L., Peppers, R. A. (1985): The influence of climate and depositional environment on the distribution and evolution of Pennsylvanian coal swamp plants. - In: Tiffney, B. (ed.), Geological Factors in the Evolution of Plants. Yale University Press, New Haven, Connecticut, pp. 223-256.

Gastaldo, R. A., DiMichele, W. A., Pfefferkorn, H. W. (1996): Out of the Icehouse into the Greenhouse: a Late Paleozoic analog for modern global vegetational change. - GSA Today, 6: 1-7.

Kerp, J. H. F. (1991): The study of fossil gymnosperms by means of cuticular analysis. - Palaios, 5: 548-569. https://doi.org/10.2307/3514861

Kerp, J. H. F., Barthel, M. (1993): Problems of cuticular analysis of pteridosperms. - Review of Palaeobotany and Palynology, 78: 1-18. https://doi.org/10.1016/0034-6667(93)90014-L

Krings, M. (2000): Zur Morphologie der Spaltöffnungsapparate von Neuropteris cordata (Pteridospermopsida, ?Medullosales) aus dem französischen Oberkarbon. - Botanische Jahrbücher für Systematik, Pflanzengeschichte und Pflanzengeographie, 122(4): 561-566.

Krings, M., Kerp, H. (1999): Morphology, growth habit and ecology of Blanzyopteris praedentata (Gothan) nov. comb., a climbing neuropteroid seed fern from the Stephanian of Central France. - International Journal of Plant Sciences, 160(3): 603-619. https://doi.org/10.1086/314154

Němejc, F. (1936): Studies on the Alethopterids of the Permocarboniferous of Central Bohemia (with remarks on forms collected in other Bohemian coaldistricts). - Věstník Královské české společnosti nauk, Tř́ída II, 1936: $1-18$.

Opluštil, S. (2005): Evolution of the Middle Westphalian river valley drainage system in central Bohemia (Czech Republic) and its palaeogeographic implication. - Palaeogeography, Palaeoclimatology, Palaeoecology, 222: 223-258. https://doi.org/10.1016/j.palaeo.2005.03.016

Opluštil, S., Schmitz, M., Cleal, C. J., Martínek, K. (2016): A review of the Middle-Late Pennsylvanian west European regional substages and floral biozones, and their correlation to the Geological Time Scale based on new U-Pb ages. - Earth-Science Reviews, 154: 301-335. https://doi.org/10.1016/j.earscirev.2016.01.004 
Opluštil, S., Sýkorová, I. (1999): Sedimentology, coal petrology and palynology of the Radnice Member in the SE part of the Kladno. - Acta Universitatis Carolinae, Geologica, 43: 599-623.

Pešek, J. (2004): Late Paleozoic limnic basins and coal deposits of the Czech Republic. - Folia Musei rerum naturalium Bohemiae, Geologica, 1: 1-188.

Phillips, T. L., Cecil, C. B. (1985): Paleoclimatic controls on coal resources of the Pennsylvanian System of North America - introduction and overview of contributions. International Journal of Coal Geology, 5: 1-6. https://doi.org/10.1016/0166-5162(85)90008-4

Phillips, T. L., Peppers, R. A. (1984): Changing patterns of Pennsylvanian coal-swamp vegetation and implications of climatic control on coal occurrence. - International Journal of Coal Geology, 3: 205-255. https://doi.org/10.1016/0166-5162(84)90019-3

Phillips, T. L., Peppers, R. A., DiMichele, W. A. (1985): Stratigraphic and interregional changes in Pennsylvanian coal-swamp vegetation: environmental inferences. International Journal of Coal Geology, 5: 43-109. https://doi.org/10.1016/0166-5162(85)90010-2

Pfefferkorn, H. W., Gillespie, W. H. (1980): Biostratigraphy and biogeography of plant compression fossils in the Pennsylvanian of North America. - In: Dilcher, D. L., Taylor, T. N. (eds), Biostratigraphy of fossil plants. Dowden, Hutchinson and Ross, Inc., Stroudsberg, Pennsylvania, pp. 93-118.

Shute, C. H., Cleal, C. J. (2002): Ecology and growth habit of Laveineopteris: a gymnosperm from the Late Carboniferous tropical rain forests. - Palaeontology, 45: 943-972. https://doi.org/10.1111/1475-4983.00270

Sternberg, K. M. von (1825): Versuch einer geognostisch-botanischen Darstellung der Flora der Vorwelt (1, 4, Tentamen). - E. Brenck's Wittwe, Regensburg, $48+$ xlii pp., pls 40-59, A-E.

Šimůnek, Z. (1988): Varieties of the species Alethopteris grandinioides Kessler from the Kladno Formation (Westphalian C, D, Bohemia). - Časopis pro mineralogii a geologii, 33: 381-394.

Šimůnek, Z. (1996): Carboniferous alethopterids of the Karviná and Žacléř Formations (Czech Republic). Sborník geologických věd, Paleontologie, 33: 5-37.
Šimůnek, Z., Cleal, C. J. (2002): The taxonomy of middle Westphalian medullosalean foliage known as 'Alethopteris grandinioides early form' from the Central and Western Bohemian basins. - Bulletin of the Czech Geological Survey, 77(1): 61-64.

Šimůnek, Z. (2007): Cuticular analysis of medullosalean pteridosperms from the Radnice Member (Pennsylvanian) of the Central and Western Bohemian basins (Czech Republic). - In: Wong, Th. E. (ed.), Proceedings of the XVth International Congress on Carboniferous and Permian Stratigraphy. Utrecht, the Netherlands, 10-16 August 2003. Royal Netherlands Academy of Arts and Sciences, Amsterdam, pp. 389-402.

Wagner, R. H. (1968): Upper Westphalian and Stephanian species of Alethopteris from Europe, Asia Minor and North America. - Mededelingen van de Rijks Geologische Dienst, Serie C, III-1(6): 1-188.

Wagner, R. H. (1974): The chronostratigraphic units of the Upper Carboniferous in Europe. - Bulletin de la Société Belge de Géologie, de Paléontologie et d'Hydrologie, 83: 235-253.

Wagner, R. H. (1984): Megafloral zones of the Carboniferous. - In: Compte rendu 9e Congrès International de Stratigraphie et de Géologie du Carbonifère (Washington, 1979), vol. 2: 109-134.

Wagner, R. H., Álvarez-Vázquez, C. (2008): A revision of the Lower Pennsylvanian Alethopteris lonchitica (auctorum) and its identity with Alethopteris urophylla. Revista Española de Paleontología, 23: 157-192.

Wagner, R. H., Sánchez de Posada, L. C., Martínez Chacón, M. L., Fernández, L. P., Villa, E., Winkler Prins, C. F. (2002): The Asturian Stage: a preliminary proposal for the definition of a substitute for Westphalian D. - In: Hills, L. V., Henderson, C. M., Bamber, E. W. (eds), Carboniferous and Permian of the World: XIV ICCP Proceedings. Memoir, the Canadian Society of Petroleum Geologists, 19: 832-850.

Zodrow, E. L., Cleal, C. J. (1998): Revision of the pteridosperm foliage Alethopteris and Lonchopteridium (Upper Carboniferous), Sydney Coalfield, Nova Scotia, Canada. - Palaeontographica, Abteilung B, 247: 65-122. 


\section{Explanations of plates}

\section{PLATE 1}

Alethopteris cf. pseudograndinioides Zodrow et Cleal, Lubná near Rakovník, Filip II Quarry, Radnice Member, fine-grained tuffites above Z-tuff, Lubná Group of coals, Bolsovian

1, 2. Part and counterpart of a pinnule, inv. no. CGS Z $\breve{S}$ 793a, b; material to slides 461/1-10.

3. Adaxial cuticle. Slide 461/7.

4, 5. Details from Fig. 3.

6 . Inner view on adaxial cuticle with prominent anticlinal walls. SEM stub 42.

7. Abaxial cuticle with prominent costal areas and intercostal areas with stomata. Slide 461/7.

8. Close up of a "structured hole" from Fig. 7.

\section{PLATE 2}

Alethopteris cf. pseudograndinioides Zodrow et CleAL, Lubná near Rakovník, Filip II Quarry, Radnice Member, fine-grained tuffites above Z-tuff, Lubná Group of coals, Bolsovian

1. Abaxial cuticle with stomata, detail from Pl. 1, Fig. 7.

2. Close up of two stomata from Fig. 1.

3. Abaxial cuticle with costal field in upper right corner, and intercostal field with stomata in left below. Slide 461/6.

4. Close up of a stomatal complex from Fig. 3. 


\section{PLATE 1}
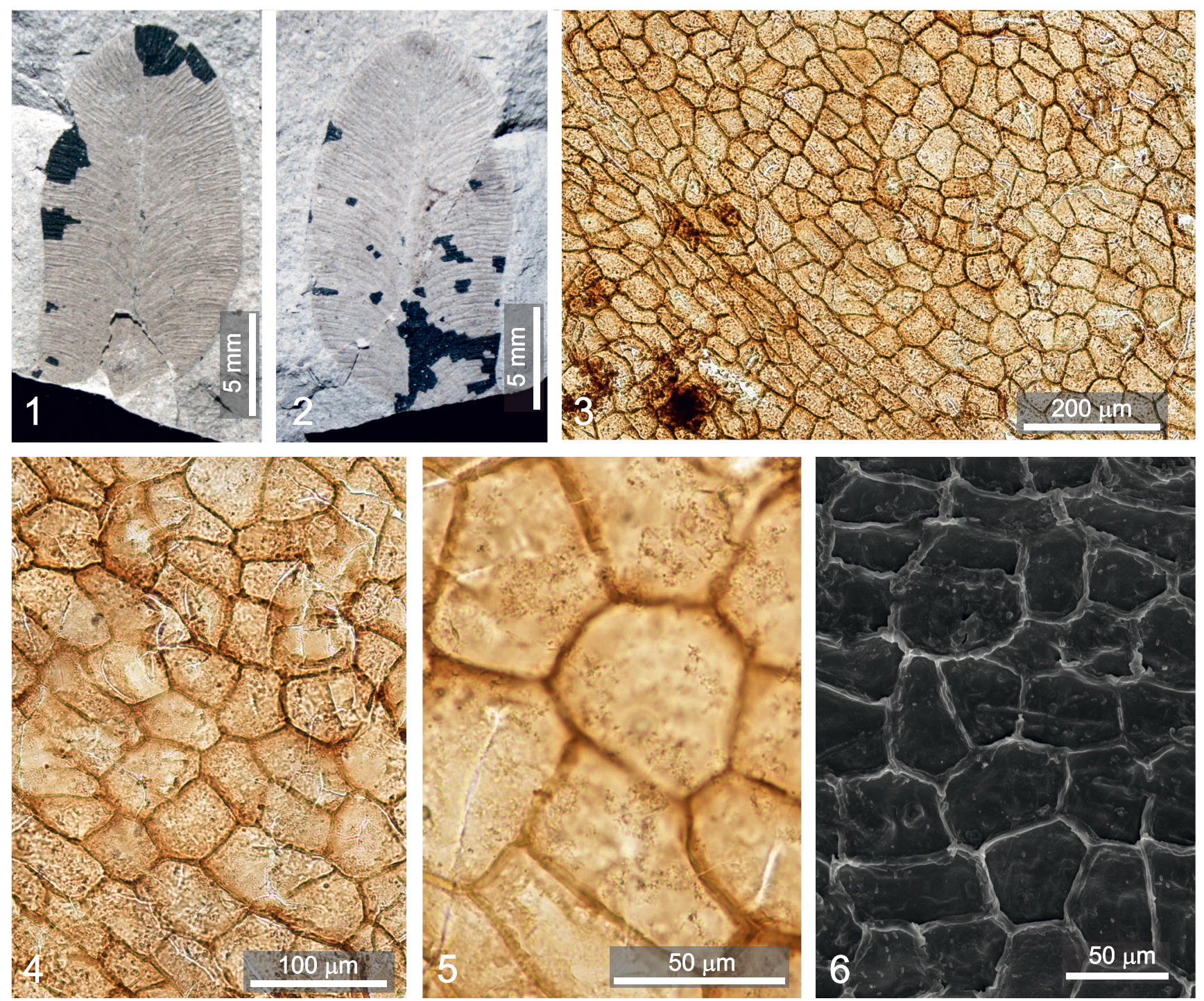

Wrives.

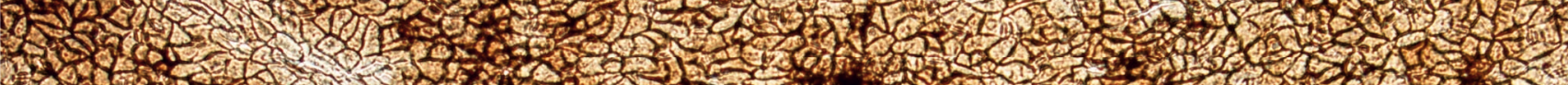

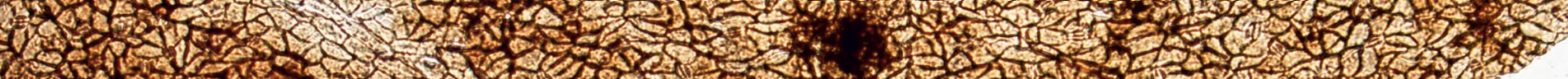

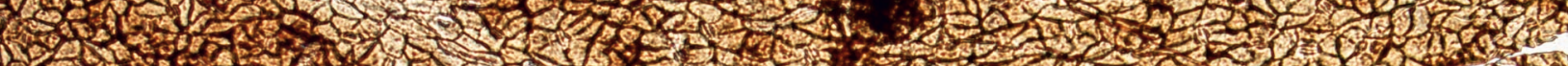

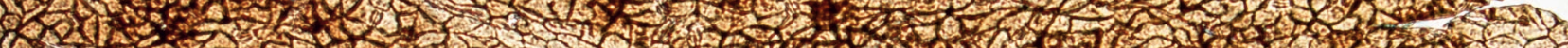

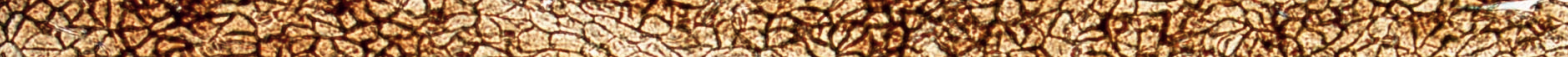

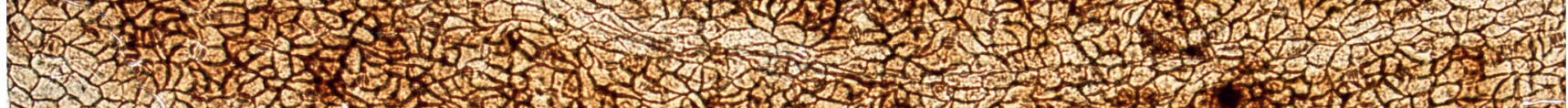

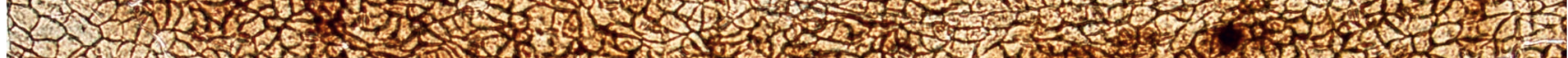

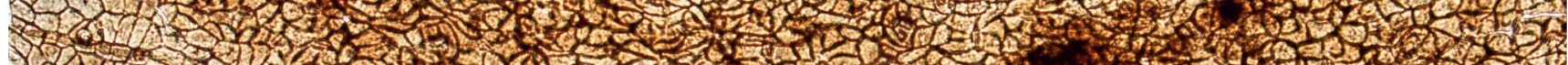

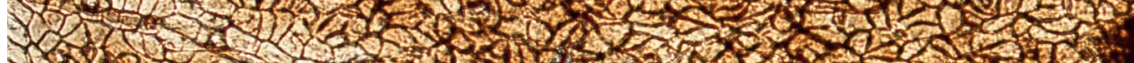

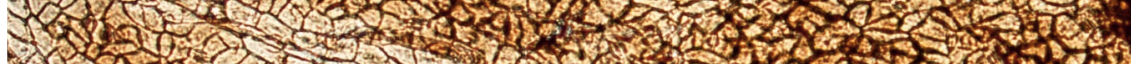

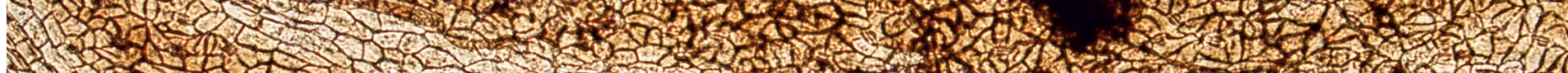
T.1. 1. T. m. 1.5. 


\section{PLATE 2}
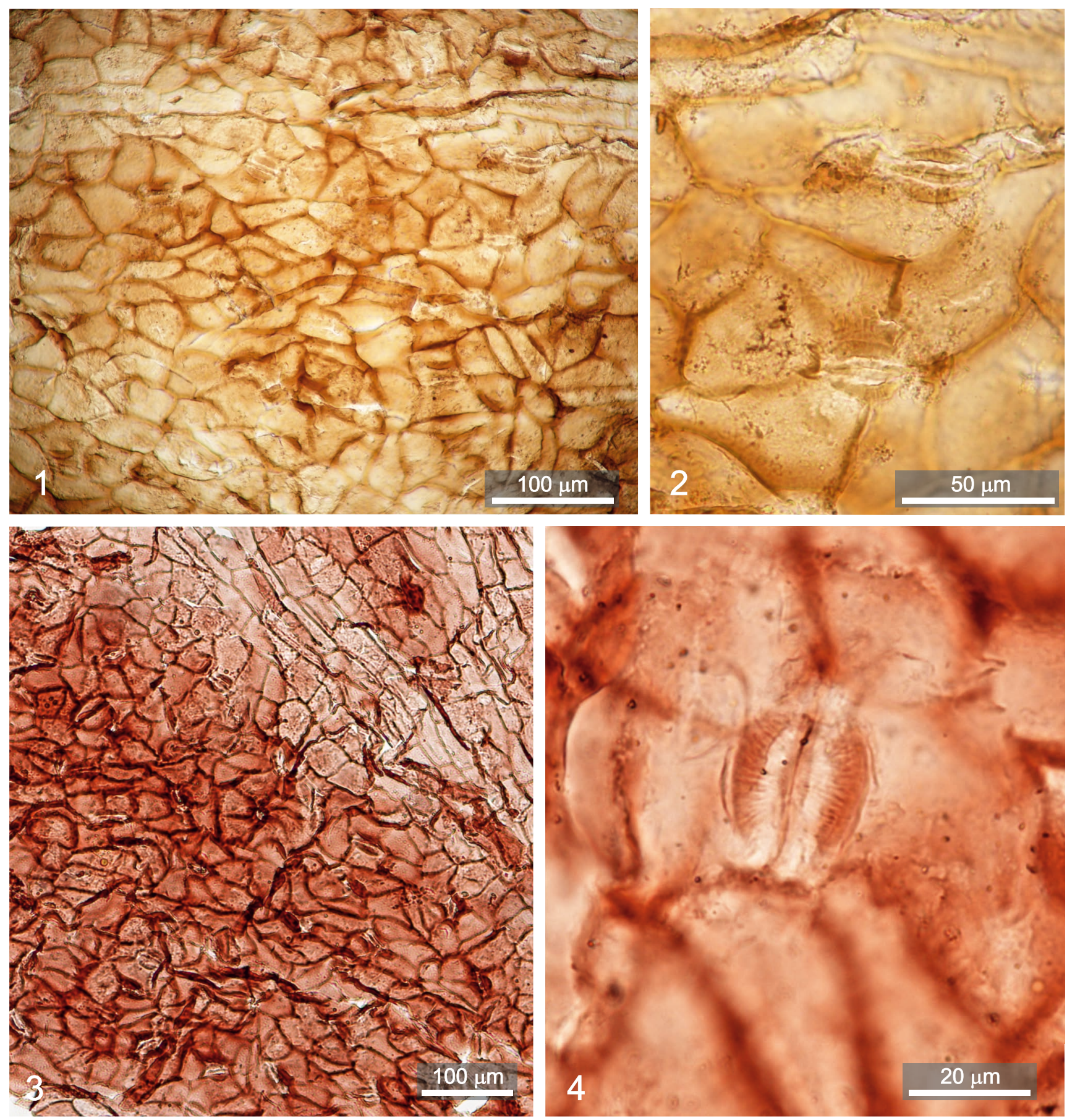